Saudi Journal of Oral and Dental Research

Abbreviated Key Title: Saudi J Oral Dent Res

ISSN 2518-1300 (Print) |ISSN 2518-1297 (Online)

Scholars Middle East Publishers, Dubai, United Arab Emirates

Journal homepage: http://scholarsmepub.com/sjodr/

\title{
Assessment of Association between Internet Addiction and Dietary Habits among College Students
}

\author{
Dr. Bhavana G ${ }^{1 *}$, Dr. Jithesh Jain ${ }^{2}$, Dr. Bhakti Jaduram Sadhu ${ }^{3}$, Dr. Ananda S R. ${ }^{4}$, Dr. Anjali Reji ${ }^{5}$ \\ ${ }^{1}$ Post Graduate student, ${ }^{2}$ Professor and Head of Department, ${ }^{3}$ Assistant professor, ${ }^{4}$ Reader, ${ }^{5}$ Post graduate student, Department of Public Health \\ Dentistry, Coorg Institute of Dental Sciences, Virajpet, Karnataka-571218, India
}

\author{
DOI: $10.36348 /$ SJODR.2019.v04i12.004 \\ | Received: 21.11.2019 | Accepted: 28.11.2019| Published: 10.12.2019 \\ *Corresponding author: Dr. Bhavana G
}

\section{Abstract}

Internet addiction has gradually become a serious issue in public health worldwide. Especially college students are vulnerable to developing dependence on the Internet, more than most other segments of the society. Hence the present was intended to assess the internet addiction and dietary habits and also to find association between internet addiction and dietary habits among college students. A cross-sectional questionnaire survey was conducted amongst 5 colleges of Coorg district. Data was collected on a semi constructed, close ended, structured questionnaire consisting sociodemographic information, questions on Internet addiction (10) and dietary habits (6). Collected Data was coded and fed in SPSS for analysis. A total of 300 students (19.86 \pm 0.94 years) were included. When the scores were tabulated, $46.1 \%$ mildly addicted, $47.2 \%$ moderately addicted and $6.6 \%$ severely addicted to internet. $20.3 \%$ occasionally found it difficult to stay away from net for several days. $26.7 \%$ of participants always lost sleep due to late night log-ins. Among severe internet addicts, $17.6 \%$ eat more when they are anxious, worried or tense $(\mathrm{p}=0.001) .64 .7 \%$ often snack more in the evening $(\mathrm{p}=0.006)$ and $58.8 \%$ of severe internet addicts took longer time to eat dinner $(\mathrm{p}=0.006)$. In the current study, internet usage had an adverse impact on the college students in terms of difficulty in staying away from net for several days, losing sleep and to certain extent on dietary habits too. Hence it is necessary to increase the public awareness regarding internet addiction and its impact on dietary habits.

Keywords: Internet addiction, college students, dietary habits.

Copyright @ 2019: This is an open-access article distributed under the terms of the Creative Commons Attribution license which permits unrestricted use, distribution, and reproduction in any medium for non-commercial use (NonCommercial, or CC-BY-NC) provided the original author and source are credited.

\section{INTRODUCTION}

In the modern world people, particularly youth primarily rely on internet which has become an integral element of everyday life for social interaction, information and entertainment as the era of newspapers and televisions is passing over[1]. Internet offers a unique venue of opportunities for their psychological development such as the chance to establish deep connections with their friends of same age group and help in their cognitive as well as academic development[2]. Though internet has many positive facets, it has got a negative face too. It is characterized by excessive or poorly controlled preoccupations, urges or behaviours regarding computer use and internet access that lead to impairment or distress[3]. Currently, internet is an indispensable element in homes, schools, cafes and businesses spaces thereby increasing the prevalence of Internet addiction rapidly[1]. College students are mostly affected by internet addiction than other segments of the society. The very same statement can be attributed to several factors including availability of time; ease of use; unlimited access to the Internet; the psychological and developmental characteristics of young adulthood; limited or no parental supervision; an expectation of Internet/computer use implicitly if not explicitly, as some courses are Internet-dependent, from assignments and projects to communication with peers and mentors; the Internet offering a route of escape from exam stress, all of which make Internet overuse a significant concern for parents and faculty[4].

Various studies ascertained the detrimental effects of Internet on several lifestyle-related factors like irregular dietary habits, extended periods of time spent on the Internet, physical inactivity, short duration of sleep and increased use of alcohol and tobacco which possibly can have a negative impact on the growth and development[1]. College students are especially vulnerable to developing dependence on the Internet, more than most other segments of the society[5]. 
According to 2015 data, India has a total number of Internet users estimated to be 354 million (i.e., $27 \%$ of the total population), of which majority comprising youths (82\%). According to The Diagnostic and Statistical Manual of Mental Disorders (DSM-5) of American Psychiatric Association (APA) Internet addiction so far is not identified as a disorder, but is being considered as an area in need of further research[5]. Many studies have showed associations between Internet addiction with mental health issues, such as depression and psychiatric symptoms, among people working in IT sector[5]. However, information on the effects of Internet addiction on the dietary behaviour of college students is limited. Therefore, the present study is intended to assess the association between internet addiction and dietary habits among college students.

\section{MATERIALS AND METHODS}

A cross sectional self- administered questionnaire survey was designed. Ethical approval was obtained from the Institutional Review Board of Coorg Institute of Dental Sciences; Virajpet. Prior permission was taken from concerned authorities of college. Consent was taken from the study participants prior to the start of study. The total number of nonhealth degree colleges in Coorg district was found to be 30 , of which five colleges were randomly selected and from each of these colleges, 60 students with the age group of 19-22 years were selected by simple random sampling method.

\section{Pilot Study}

A pilot study was conducted on 10 subjects to check for the validity, reliability of the questionnaire and the prevalence of internet addiction. Cronbach's alpha value was calculated to be 0.82 (good). These 10 subjects were not included in the final study.

\section{Sample size}

Based on the pilot study, the prevalence of internet addiction was found to be $26 \%$. The sample size was calculated using this formula

$$
\begin{gathered}
n=\frac{\mathrm{Z} \alpha 2 \mathrm{p}(1-\mathrm{p})}{d 2} \\
n=\frac{1.96 * 1.96 * 0.26 * 0.74}{0.05 * 0.05} \\
n=\frac{1.96 * 1.96 * 0.26 * 0.74}{0.0025} \\
\mathbf{n}=\mathbf{2 9 5 . 6}
\end{gathered}
$$

Which was rounded off to $\underline{\mathbf{3 0 0}}$

\section{Study Procedure}

After explaining the study protocol, a prevalidated, closed end questionnaire was given to each participant. Each subject was given 15 minutes to complete the questionnaire. The proforma included Demographic information like age, sex and year of study followed by 16 questions addressing a series of items regarding Internet addiction and dietary habits. Questionnaire included - Ten questions about Internet addiction and six questions on Dietary habits. The language of the questionnaire was English and it was a multiple-choice question.

\begin{tabular}{|l|l|}
\hline \begin{tabular}{|l|}
300 students were given the \\
questionnaire
\end{tabular} & $\begin{array}{l}42 \text { were excluded as they } \\
\text { did not meet the scoring } \\
\text { criteria (i.e. score }<10)\end{array}$ \\
\hline 258 were included in study
\end{tabular}

\section{DATA ANALYSIS}

The data was collected, coded and fed into the SPSS (Statistical Package for Social Sciences, version 21) for statistical analysis. Descriptive statistics included the frequency and percentage. Inferential statistics was calculated for categorical data using Chisquare test. Level of significance was set at 0.05 and was considered as statistically significant.

\section{RESULTS}

The present cross sectional study was conducted among 300 students studying in various degree colleges of Coorg district. Among 300 participants, 161 were male with mean age of $20.05 \pm$ 0.923 and 139 were females with mean age of $19.86 \pm$ 0.94 years respectively as shown in Table 1 .

Table 2 shows that majority of the participants i.e. $40.3 \%$ are studying in $2^{\text {nd }}$ year, $38.3 \%$ of the participants are studying in $1^{\text {st }}$ year and only $21.3 \%$ of the participants are studying in $3^{\text {rd }}$ year of college.

Table 3 shows the level of internet addiction among study subjects based on the scores. $46.1 \%$ of the subjects were found to be mildly addicted to internet, where as $47.2 \%$ moderately addicted and $6.5 \%$ were severely addicted.

Table 4 shows the distribution of responses to questions based on internet addiction. The association between "I often have my breakfast before going to college" and internet addiction was found to be statistically non-significant $(\mathrm{p}=0.088)$ [Table 4A]. Whereas the chi square analysis for the question "I purposefully hold back at meals in order not to gain weight" and internet addiction was found to be statistically significant $(\mathrm{p}=0.037)$ [Table 4B]. Similarly the chi-square analysis for "I tend to eat more when I am anxious, worried or tense" and internet addiction was found to be statistically highly-significant $(\mathrm{p}=0.001)$ [Table 4C]. The chi-square analysis for the question - "I tend to eat more food than usual when I have more available places that serve or sell food" and 
Bhavana G et al; Saudi J Oral Dent Res, Dec., 2019; 4(12): 801-806

internet addiction was found to be statistically significant $(\mathrm{p}=0.009) \quad[$ Table 4D]. Further the association between "I often take long time to eat dinner" and internet addiction was found to be statistically significant $(\mathrm{p}=0.006)$ [Table 4E]. Similarly the association between "I often snack more in the evening" and internet addiction was found to be statistically significant $(\mathrm{p}=0.006)$ [Table 4F].
Table-1: Distribution of study subjects based on gender.

\begin{tabular}{|c|c|c|c|}
\hline Gender & $\mathbf{N}$ & Mean Age & Std. Deviation \\
\hline Male & 161 & 20.0500 & .92349 \\
\hline Female & 139 & 19.8643 & .94611 \\
\hline
\end{tabular}
$\mathrm{t}=1.718, \mathrm{p}=0.087$ Non-Significant.

Table-2: Distribution of study subjects based on gender and year of study

\begin{tabular}{|c|c|c|c|c|c|}
\hline & & \multicolumn{3}{|c|}{ Year of study } & \multirow{2}{*}{ Total } \\
\hline & & $1^{\text {st }}$ YEAR & $2^{\text {nd }}$ YEAR & $3^{\text {rd }}$ YEAR & \\
\hline \multirow{2}{*}{ Gender } & Male & $\begin{array}{c}53 \\
(32.9 \%)\end{array}$ & $\begin{array}{c}70 \\
(43.5 \%)\end{array}$ & $\begin{array}{c}38 \\
(23.6 \%)\end{array}$ & $\begin{array}{c}161 \\
(100 \%)\end{array}$ \\
\hline & Female & $\begin{array}{c}62 \\
(44.6 \%)\end{array}$ & $\begin{array}{c}51 \\
(36.7 \%)\end{array}$ & $\begin{array}{c}26 \\
(18.7 \%)\end{array}$ & $\begin{array}{c}139 \\
(100 \%)\end{array}$ \\
\hline \multicolumn{2}{|c|}{ Total } & $\begin{array}{c}115 \\
(38.3 \%)\end{array}$ & $\begin{array}{c}121 \\
(40.3 \%)\end{array}$ & $\begin{array}{c}64 \\
(21.3 \%)\end{array}$ & $\begin{array}{c}300 \\
(100 \%)\end{array}$ \\
\hline
\end{tabular}

Table-3: Distribution of study subjects based on internet addiction

\begin{tabular}{|l|c|c|c|}
\hline & Internet addiction score & Number & Percentage \\
\hline Mild & Score 10-24 & 119 & $46.1 \%$ \\
\hline Moderate & Score 25-39 & 122 & $47.2 \%$ \\
\hline Severe & Score 40-50 & 17 & $6.5 \%$ \\
\hline
\end{tabular}

Table 4: Distribution of responses to questions based on internet addiction

Table-4A: Q1 - I often have my breakfast before going to college

\begin{tabular}{|c|c|c|c|c|c|c|}
\hline \multirow{2}{*}{ Internet addiction } & \multicolumn{5}{|c|}{ Response } & \multirow{2}{*}{ Total } \\
\hline & Not at all & Slightly & Less & Pretty well & Completely & \\
\hline Mild & $\begin{array}{c}7 \\
(5.9 \%)\end{array}$ & $\begin{array}{c}26 \\
(21.8 \%)\end{array}$ & $\begin{array}{c}31 \\
(26.1 \%)\end{array}$ & $\begin{array}{c}24 \\
(20.2 \%)\end{array}$ & $\begin{array}{c}31 \\
(26.1 \%)\end{array}$ & $\begin{array}{c}119 \\
(100 \%)\end{array}$ \\
\hline Moderate & $\begin{array}{c}15 \\
(12.3 \%)\end{array}$ & $\begin{array}{c}29 \\
(23.8 \%)\end{array}$ & $\begin{array}{c}32 \\
(26.2 \%)\end{array}$ & $\begin{array}{c}30 \\
(24.6 \%)\end{array}$ & $\begin{array}{c}16 \\
(13.1 \%)\end{array}$ & $\begin{array}{c}122 \\
(100 \%)\end{array}$ \\
\hline Severe & $\begin{array}{c}3 \\
(17.6 \%)\end{array}$ & $\begin{array}{c}1 \\
(5.9 \%)\end{array}$ & $\begin{array}{c}3 \\
(17.6 \%)\end{array}$ & $\begin{array}{c}4 \\
(23.5 \%)\end{array}$ & $\begin{array}{c}6 \\
(35.3 \%)\end{array}$ & $\begin{array}{c}17 \\
(100 \%)\end{array}$ \\
\hline & $\begin{array}{c}25 \\
(9.7 \%) \\
\end{array}$ & $\begin{array}{c}56 \\
(21.7 \%) \\
\end{array}$ & $\begin{array}{c}66 \\
(25.6 \%) \\
\end{array}$ & $\begin{array}{c}58 \\
(22.5 \%) \\
\end{array}$ & $\begin{array}{c}53 \\
(20.5 \%) \\
\end{array}$ & $\begin{array}{c}258 \\
(100 \%) \\
\end{array}$ \\
\hline
\end{tabular}

$\mathrm{X}^{2}=13.764, \mathrm{p}=0.088$ Non-Significant.

Table-4B: Q2 - I purposefully hold back at meals in order not to gain weight

\begin{tabular}{|c|c|c|c|c|c|c|}
\hline \multirow{2}{*}{ Internet addiction } & \multicolumn{5}{|c|}{ Response } & \multirow{2}{*}{ Total } \\
\hline & Not at all & Slightly & Less & Pretty well & Completely & \\
\hline Mild & $\begin{array}{c}58 \\
(48.7 \%)\end{array}$ & $\begin{array}{c}17 \\
(14.3 \%)\end{array}$ & $\begin{array}{c}31 \\
(26.1 \%)\end{array}$ & $\begin{array}{c}9 \\
(7.6 \%)\end{array}$ & $\begin{array}{c}4 \\
(3.4 \%)\end{array}$ & $\begin{array}{c}119 \\
(100 \%)\end{array}$ \\
\hline Moderate & $\begin{array}{c}35 \\
(28.7 \%)\end{array}$ & $\begin{array}{c}24 \\
(19.7 \%)\end{array}$ & $\begin{array}{c}35 \\
(28.7 \%)\end{array}$ & $\begin{array}{c}16 \\
(13.1 \%)\end{array}$ & $\begin{array}{c}12 \\
(9.8 \%)\end{array}$ & $\begin{array}{c}122 \\
(100 \%)\end{array}$ \\
\hline Severe & $\begin{array}{c}9 \\
(52.9 \%)\end{array}$ & $\begin{array}{c}1 \\
(5.9 \%)\end{array}$ & $\begin{array}{c}5 \\
(29.4 \%)\end{array}$ & $\begin{array}{c}2 \\
(11.8 \%)\end{array}$ & $\begin{array}{c}0 \\
(.0 \%)\end{array}$ & $\begin{array}{c}17 \\
(100 \%)\end{array}$ \\
\hline & $\begin{array}{c}102 \\
(39.5 \%)\end{array}$ & $\begin{array}{c}42 \\
(16.3 \%)\end{array}$ & $\begin{array}{c}71 \\
(27.5 \%)\end{array}$ & $\begin{array}{c}27 \\
(10.5 \%)\end{array}$ & $\begin{array}{c}16 \\
(6.2 \%)\end{array}$ & $\begin{array}{c}258 \\
(100 \%)\end{array}$ \\
\hline
\end{tabular}


Bhavana G et al; Saudi J Oral Dent Res, Dec., 2019; 4(12): 801-806

Table-4C: Q3 - I tend to eat more when I am anxious, worried or tense

\begin{tabular}{|c|c|c|c|c|c|c|}
\hline \multirow{2}{*}{ Internet addiction } & \multicolumn{7}{|c|}{ Response } & \multirow{2}{*}{ Total } \\
\cline { 2 - 7 } Mild & Not at all & Slightly & Less & Pretty well & Completely & \\
\hline \multirow{2}{*}{ Moderate } & 40 & 29 & 21 & 16 & 13 & 119 \\
& $(33.6 \%)$ & $(24.4 \%)$ & $(17.6 \%)$ & $(13.4 \%)$ & $(10.9 \%)$ & $(100 \%)$ \\
\hline \multirow{2}{*}{ Severe } & 22 & 16 & 35 & 27 & 22 & 122 \\
& 3 & 7 & 0 & 4 & 3 & 17 \\
& $(17.6 \%)$ & $(41.2 \%)$ & $(.0 \%)$ & $(23.5 \%)$ & $(17.6 \%)$ & $(100 \%)$ \\
\hline & 65 & 52 & 56 & 47 & 38 & 258 \\
& $(25.2 \%)$ & $(20.2 \%)$ & $(21.7 \%)$ & $(18.2 \%)$ & $(14.7 \%)$ & $(100 \%)$ \\
\hline
\end{tabular}

$\mathrm{X}^{2}=26.27, \mathrm{p}=0.001$ Highly Significant.

Table-4D: Q4 - I tend to eat more food than usual when I have more available places that serve or sell food

\begin{tabular}{|c|c|c|c|c|c|c|}
\hline \multirow[t]{2}{*}{ Internet addiction } & \multicolumn{5}{|c|}{ Response } & \multirow[t]{2}{*}{ Total } \\
\hline & Not at all & Slightly & Less & Pretty well & Completely & \\
\hline Mild & $\begin{array}{c}30 \\
(25.2 \%)\end{array}$ & $\begin{array}{c}24 \\
(20.2 \%)\end{array}$ & $\begin{array}{c}23 \\
(19.3 \%)\end{array}$ & $\begin{array}{c}27 \\
(22.7 \%)\end{array}$ & $\begin{array}{c}15 \\
(12.6 \%)\end{array}$ & $\begin{array}{c}119 \\
(100 \%)\end{array}$ \\
\hline Moderate & $\begin{array}{c}21 \\
(17.2 \%)\end{array}$ & $\begin{array}{c}21 \\
(17.2 \%)\end{array}$ & $\begin{array}{c}29 \\
(23.8 \%)\end{array}$ & $\begin{array}{c}20 \\
(16.4 \%)\end{array}$ & $\begin{array}{c}31 \\
(25.4 \%)\end{array}$ & $\begin{array}{c}122 \\
(100 \%)\end{array}$ \\
\hline \multirow[t]{2}{*}{ Severe } & $\begin{array}{c}1 \\
(5.9 \%)\end{array}$ & $\begin{array}{c}3 \\
(17.6 \%)\end{array}$ & $\begin{array}{c}2 \\
(11.8 \%)\end{array}$ & $\begin{array}{c}2 \\
(11.8 \%)\end{array}$ & $\begin{array}{c}9 \\
(52.9 \%)\end{array}$ & $\begin{array}{c}17 \\
(100 \%)\end{array}$ \\
\hline & $\begin{array}{c}52 \\
(20.2 \%)\end{array}$ & $\begin{array}{c}48 \\
(18.6 \%)\end{array}$ & $\begin{array}{c}54 \\
(20.9 \%)\end{array}$ & $\begin{array}{c}49 \\
(19.0 \%)\end{array}$ & $\begin{array}{c}55 \\
(21.3 \%)\end{array}$ & $\begin{array}{c}258 \\
(100 \%)\end{array}$ \\
\hline
\end{tabular}

Table-6E: Q5 - I often take long time to eat dinner

\begin{tabular}{|c|c|c|c|c|c|c|}
\hline \multirow{2}{*}{ Internet addiction } & \multicolumn{5}{|c|}{ Response } & \multirow{2}{*}{ Total } \\
\hline & Not at all & Slightly & Less & Pretty well & Completely & \\
\hline Mild & $\begin{array}{c}27 \\
(22.7 \%)\end{array}$ & $\begin{array}{c}26 \\
(21.8 \%)\end{array}$ & $\begin{array}{c}17 \\
(14.3 \%)\end{array}$ & $\begin{array}{c}25 \\
(21.0 \%)\end{array}$ & $\begin{array}{c}24 \\
(20.2 \%)\end{array}$ & $\begin{array}{c}119 \\
(100 \%)\end{array}$ \\
\hline Moderate & $\begin{array}{c}12 \\
(9.8 \%) \\
\end{array}$ & $\begin{array}{c}20 \\
(16.4 \%) \\
\end{array}$ & $\begin{array}{c}25 \\
(20.5 \%)\end{array}$ & $\begin{array}{c}31 \\
(25.4 \%) \\
\end{array}$ & $\begin{array}{c}34 \\
(27.9 \%) \\
\end{array}$ & $\begin{array}{c}122 \\
(100 \%)\end{array}$ \\
\hline Severe & $\begin{array}{c}2 \\
(11.8 \%)\end{array}$ & $\begin{array}{c}2 \\
(11.8 \%)\end{array}$ & $\begin{array}{c}0 \\
(.0 \%)\end{array}$ & $\begin{array}{c}3 \\
(17.6 \%)\end{array}$ & $\begin{array}{c}10 \\
(58.8 \%)\end{array}$ & $\begin{array}{c}17 \\
(100 \%)\end{array}$ \\
\hline & $\begin{array}{c}41 \\
(15.9 \%)\end{array}$ & $\begin{array}{c}48 \\
(18.6 \%)\end{array}$ & $\begin{array}{c}42 \\
(16.3 \%)\end{array}$ & $\begin{array}{c}59 \\
(22.9 \%)\end{array}$ & $\begin{array}{c}68 \\
(26.4 \%)\end{array}$ & $\begin{array}{c}258 \\
(100 \%)\end{array}$ \\
\hline
\end{tabular}

Table-6F: Q6 - I often snack more in the evening

\begin{tabular}{|c|c|c|c|c|c|c|}
\hline \multirow{2}{*}{ Internet addiction } & \multicolumn{7}{|c|}{ Response } & \multirow{2}{*}{ Total } \\
\cline { 2 - 7 } & Not at all & Slightly & Less & Pretty well & Completely & \\
\hline \multirow{2}{*}{ Mild } & 12 & 28 & 31 & 24 & 24 & 119 \\
& $(10.1 \%)$ & $(23.5 \%)$ & $(26.1 \%)$ & $(20.2 \%)$ & $(20.2 \%)$ & $(100 \%)$ \\
\hline Moderate & 5 & 20 & 27 & 29 & 41 & 122 \\
& $(4.1 \%)$ & $(16.4 \%)$ & $(22.1 \%)$ & $(23.8 \%)$ & $(33.6 \%)$ & $(100 \%)$ \\
\hline Severe & 1 & 4 & 0 & 1 & 11 & 17 \\
& $(5.9 \%)$ & $(23.5 \%)$ & $(.0 \%)$ & $(5.9 \%)$ & $(64.7 \%)$ & $(100 \%)$ \\
\hline & 24 & 62 & 69 & 59 & 86 & 258 \\
& $(8.0 \%)$ & $(20.7 \%)$ & $(23.0 \%)$ & $(19.7 \%)$ & $(28.7 \%)$ & $(100 \%)$ \\
\hline
\end{tabular}

\section{DISCUSSION}

The present cross sectional study was conducted to assess the association between internet addiction and dietary habits among college students. A total of 300 students studying in various professional and non-professional colleges of Coorg district participated in the study. For this study, college students between 19-22 years of age were chosen, as during this period they are exclusively vulnerable towards developing dependence on the Internet, more than other segments of the society. This could be accredited to numerous factors such as availability of time; ease of use; unlimited access to the Internet; the psychological 
and developmental characteristics of young adulthood; limited or no parental supervision; an expectation of Internet/computer use implicitly if not explicitly, as certain courses are reliant on internet, from assignments and projects to communication with peers and mentors; the Internet offers a route of escape from exam stress, all of which make Internet overuse a significant cause of concern for parents and faculty[4].

In the present study, the mean age of study participants was found to be $19.86 \pm 0.94$ years, which was in accordance with the study done by Arvind Sharma et $\mathrm{al}^{6}$, where the mean age of the subjects was $19.02 \pm 1.450$ years.

In the present study, $46.1 \%$ of the subjects were found to be mildly addicted to internet, where as $47.2 \%$ were moderately addicted and $6.5 \%$ were severely addicted. The results are in contrast with the study done by Arvind Sharma et al. [6], where 57.3\% of the participants were normal users while $35.0 \%$ of the participants were mildly addicted to internet, $7.4 \%$ participants had moderate addiction and $0.3 \%$ of them had severe addiction to internet. In a study conducted by Naffise Mashaei et al. [7], the prevalence of internet addiction among students of Rafsanjan University of Medical Sciences, Iran, 51.3\% had mild internet addiction, $5.4 \%$ of the participants had moderate and $0.9 \%$ of the participants were severely addicted to internet.

In the present study, $12.0 \%$ of the participants spend often more time in surfing the net, whereas $6.7 \%$ always spend more time in surfing the net. The results are in contrast with the study done by Najmi Hayati Usma et al. [8] in Malaysia, wherein $11.7 \%$ often and $33.3 \%$ always spend more time in surfing the net. A study done by Chien chou [2] among college students, explained that the possible reason for spending more time in surfing the net could be due to usage of e-mail, developing a sense of companionship (belonging), monitoring environments, searching useful information to improve living, killing time and having fun and gratification; and most of the information we need in our daily lives (e.g., from mass media) can be easily and cheaply obtained from the Internet, and activities such as making phone calls, writing letters can also be carried out from the Internet, it is no leap to predict that more and more students will spend more and more time on the Internet.

In the present study, $38 \%$ of respondents lost their sleep due to late night log-ins. These findings are in accordance with the study done by Rohith M[5] among IT Professionals in Bangalore, wherein 39.7\% lost their sleep due to late night log-ins. The possible reason could be, as IT professionals they are compelled to use Internet for prolonged periods of time because of the nature of their occupation.
In the present study, $23.4 \%$ of the participants responded that their friends or family members always complained about their time spent at computer. These findings were in contrast with the study done by Kausar Suhai et al. [9], wherein $49.0 \%$ of the participants responded that their friends or family members always complained about their time spent at computer. This could be explained by some evidence that as Internet use increases, users are more likely to spend less time talking to family and friends and attending social events. On the other hand, use of Internet for purely entertainment purpose may not have any time limit. Highly interactive activities like emailing, surfing, multi-player games, chat forums etc. may facilitate addiction behavior.

In the present study, $12.7 \%$ reported that they always find hard to stay away from the net several days at a time. These findings are in consistent with the results obtained by Kausar Suhai et al. [9], where $25.0 \%$ found themselves hard to stay away from the net several days at a time.

In the present study, $17.6 \%$ skipped their breakfast before going to college. The results are in accordance with the study conducted by Yeonsoo Kim et al.[1], where $47.3 \%$ skipped their breakfast.

In the present study, $58.8 \%$ of the participants took longer time to eat dinner. This result is in contrast with the study done by Yeonsoo Kim et al. [1], where only $17.2 \%$ of the participants took longer time to eat.

In the present study, $64.7 \%$ of the participants snaked often. This finding is in consistent with the study done by Rohith $M$ et al. [5], where $82 \%$ of severely addicted participants consumed junk food on a daily basis.

This study has several limitations. First, since the cross-sectional nature of the study provides only associative results, which are insufficient to draw any causal inference between internet addiction and dietary habits. Secondly the questionnaire which was used to assess the internet addiction as well as dietary habits was not standardized. Various other factors such as socio-economic status, family income and pocket money of the students were also not assessed in this index study. Future studies should be conducted with more precise measurement on various potential risk factors.

However, strength of our study was providing an overview of burden of the internet addiction and dietary habits among college students aged $19-22$ years in Virajpet for the first time and it can be a benchmark for future comparisons by the public health personnel and decision makers. 


\section{CONCLUSION}

The findings of the present study emphasized that excessive use of internet have affected the dietary habits of the college students to some extent. Internet addiction can inversely affect the individuals quality of life i.e. both subjective (life satisfaction) and objective (quality of environmental conditions). Therefore awareness should be created among the college students concerning internet usage to improve their ability to reduce the incidence of internet addiction behavior and necessary health intervention strategies should be developed. Further research have to be conducted to determine the relation of internet addiction and dietary habits, a topic that has been underexplored in the literature. Consequently parents and caregivers must monitor the Internet use and activity of the students and close attention should be paid to students at risk of Internet addiction, as well as students at low risk to prevent them from becoming addicted to the Internet.

\section{REFERENCES}

1. Kim, Y., Park, J. Y., Kim, S. B., Jung, I. K., Lim, Y. S., \& Kim, J. H. (2010). The effects of Internet addiction on the lifestyle and dietary behavior of Korean adolescents. Nutrition research and practice, 4(1), 51-57.

2. Chou, C. (2001). Internet heavy use and addiction among Taiwanese college students: an online interview study. CyberPsychology \& Behavior, 4(5), 573-585.
3. Shaw, M., \& Black, D. W. (2008). Internet addiction. CNS drugs, 22(5), 353-365.

4. Krishnamurthy, S., \& Chetlapalli, S. K. (2015) Internet addiction: Prevalence and risk factors: A cross-sectional study among college students in Bengaluru, the Silicon Valley of India. Indian journal of public health, 59(2), 115.

5. Rohith, M., \& Patil, S. S. (2017). Prevalence of internet addiction amongst the IT professionals of Bangalore city and its effect on their lifestyle and dietary habits. International Journal Of Community Medicine And Public Health, 4(6), 2132-2135.

6. Sharma, A., Sahu, R., Kasar, P. K., \& Sharma, R. (2014). Internet addiction among professional courses students: A study from central India. Int J Med Sci Public Health, 3(9), 1069-73.

7. Naffise, M., Mohammad, A., Ahmad, P. B., Omid, R., Reza, B., \& Fatemeh, A. B. (2013). The prevalence of internet addiction among the students of rafsanjan university of medical sciences. ASEAN Journal of Psychiatry, 14(2).

8. Usman, N. H., Alavi, M., \& Shafeq, S. M. (2014). Relationship between Internet addiction and academic performance among foreign undergraduate students. Procedia-Social and Behavioral Sciences, 114, 845-851.

9. Suhail, K., \& Bargees, Z. (2006). Effects of excessive Internet use on undergraduate students in Pakistan. CyberPsychology \& Behavior, 9(3), 297307/ 